Historic, Archive Document

Do not assume content reflects current scientific knowledge, policies, or practices. 

PRICE LIST

\title{
Northwestern Nursery
}

\author{
BECKMAN BROS., Props.
}

NURSERY -4 miles north of Sebastopol, I mile northeast of Graton. Postoffice, Sebastopol, Calif., R. F. D., Box 146.

\section{SEASON 1920-21 \\ GUARANTEE}

All trees and plants raised in our nursery are guaranteed rue to name as fas as any reliable nursery can do so, and every possible care is taken to prevent mistakes. Should any mistakes occur, however, we agree, upon proper proof being made, to replace any tree that may not prove true to label, free of charge, or refund to the purchaser of such trees the original cost of trees. It is hereby understood and agreed between purchaser and ourselves that we are not to be held liable for any greater sum. We solicit your patronage, but cannot in justice to ourselves, accept orders on any other terms.

All orders should be plainly written on a separate sheet of paper and not mixed up in the body of the letter. This prevents mistakes in booking orders. Advise us plainly how you wish us to ship-by freight or express. Also state route. Otherwise we will use our own judgment in forwarding.

Parties unknown to us must accompany their orders with a remittance or furnish satisfactory references.

Articles mentioned in the list will be furnished at prices named as follows: Five at the 10-rate, 50 at the 100-rate; 500 or more at the 1,000-rate. Less than five of a variety at the single rate. BECKMAN BROS.

NOTICE-Prices subject to change without notice. 


\section{APPLES}

Each $\quad 10 \quad 100$

1 to 2 yr., $1 / 2$ to $5 / 8$ in. in dia.,

4 to $6 \mathrm{ft}$. $60 \mathrm{c} \quad \$ 5.50 \quad \$ 50.00$

1 to $2 \mathrm{yr}$., $3 / 8$ to $1 / 2$ in. in dia.,

3 to $4 \mathrm{ft}$. $\begin{array}{lll}.55 \mathrm{c} & 5.00 & 45.00\end{array}$

1 to 2 yr., 2 to $3 \mathrm{ft}$. $\begin{array}{lll}50 \mathrm{c} & 4.50 \quad 40.00\end{array}$

Ark. Black

Baldvin

Gravenstein

Jonathan

Northern Spy

Rhode Island Greening

Smith Cider

W. W. Pearmain

Alexander

Ben Davis

Beileflower, Yellow

Hoover

King of Tompkins Co.

Yellow Newtown

$$
\text { Pippin }
$$

Red June

Rome Beauty

Spitzenberg

Wagner

Winesap

\section{CRAB APPLES}

1 to $2 \mathrm{yr}$., 4 to $6 \mathrm{ft}$., $1 / 2$ to $5 / 8$ in. in dia. ....Each $60 \mathrm{c}$

1 to $2 \mathrm{yr}$., 3 to $4 \mathrm{ft}$., $3 / 3$ to $1 / 2$ in. in dio. ..Each $50 \mathrm{c}$

Red Siberian

Transcendent

\section{PEARS}

Each $\quad 10 \quad 100$

$1 \mathrm{yr} ., 4$ to $6 \mathrm{ft}$., $1 / 2$ to $5 / \%$ in. in dia. $60 \mathrm{c} \quad \$ 5.50 \$ 50.00$

$1 \mathrm{yr} ., 3$ to $4 \mathrm{ft}$.. $\%$ to $1 / 2 \mathrm{in}$. in dia. $55 \mathrm{c} \quad 5.00 \quad 45.00$

$1 \mathrm{yr} ., 2$ to $3 \mathrm{ft}$. .............................50 $4.50 \quad 40.00$

Bartlett

Winter Nellis

\section{PLUMS ON MYROBOLAN ROOT}

1 to $2 \mathrm{yr}$., 4 to $6 \mathrm{ft}$., $1 / 2$ to $5 / \mathrm{s}$ in. in dia. $60 \mathrm{c} \$ 5,50 \$ 50.00$

$1 \mathrm{yr} . .3$ to $4 \mathrm{ft}$., $3 / 8$ to $1 / 2 \mathrm{in}$. in dia. $\begin{array}{lll}50 \mathrm{c} & 5.00 & 45.00\end{array}$ Burbank, Jefferson, Yellow Egg, Washington 


\section{PRUNES ON MYROBOLAN ROOT}

Each $\quad 10 \quad 100$

1 to $2 \mathrm{yr}$., 4 to $6 \mathrm{ft}$., $5 / 8$ to $1 / 2$ in. in dia.

1 to $2 \mathrm{yr}$., 4 to $6 \mathrm{ft}$., $1 / 2$ to $5 / 8$ in. in dia.

1 to $2 \mathrm{yr}$., 2 to $3 \mathrm{ft}$. $\begin{array}{lll}.55 \mathrm{c} & 5.00 & 45.00\end{array}$ French

Standard . $.50 \mathrm{c} \quad 4.50 \quad 40.00$ $.60 \mathrm{c} \quad \$ 5.50 \quad \$ 50.00$

\section{APRICOTS}

Imperial

Each 10

$1 \mathrm{yr}, 4$ to $6 \mathrm{ft}$., $5 / 8$ to $3 / 4$ in. in dia...............60 $\$ 5.50$

$1 \mathrm{yr}$., 3 to $4 \mathrm{ft}$., $3 / 8$ to $5 / 8$ in. in dia. ................5 5.00 Montgomery Blenheim Royal

\section{QUINCES}
1 yr., 3 to
Champion
Each 10 dia.....55c $\$ 5.00$
Pine Apple

\section{PEACHES}

\begin{tabular}{|c|c|c|c|}
\hline & Each & 10 & 100 \\
\hline $\begin{array}{l}1 \mathrm{yr} ., 4 \text { to } 6 \mathrm{ft} \text {. ............. } \\
1 \mathrm{yr}, 3 \text { to } 4 \mathrm{ft} . \ldots \ldots \ldots . .\end{array}$ & 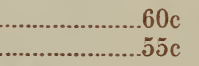 & $\begin{array}{r}\$ 5.50 \\
5.00\end{array}$ & $\begin{array}{r}\$ 50.00 \\
45.00\end{array}$ \\
\hline $\begin{array}{l}\text { Alexander } \\
\text { Early. Crawford } \\
\text { Elberta } \\
\text { Runyan Orange Cling } \\
\text { Hale's Early }\end{array}$ & $\begin{array}{l}\text { Phillips Cling } \\
\text { Muir } \\
\text { Tuscan Cling } \\
\text { Salaway } \\
\text { Wiley Cling }\end{array}$ & & 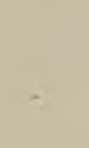 \\
\hline
\end{tabular}

\section{CHERRIES}

Each $10 \quad 100$

1 to 2 yr., 4 to $6 \mathrm{ft}$., $1 / 2$ to $\%$ in.

in dia.

1 to $2 \mathrm{yr}$., 3 to $4 \mathrm{ft}$., $3 / 8$ to $1 / 2 \mathrm{in}$.

in dia.

$60 \mathrm{c} \quad \$ 5.50 \quad \$ 50.00$ $\begin{array}{lll}.55 \check{c} & 5.00 & 45.00\end{array}$

Royal Ann

Rockport

Black Republican

\section{Bing}

Lambert

Black Tartarian

3 


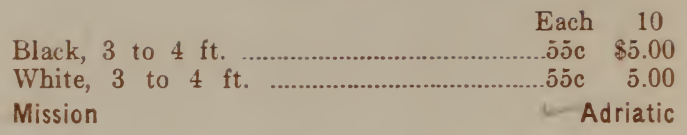

\section{CITRUS FRUITS}

Prices on application.

\section{BERRIES}

Each $10 \quad 100 \quad 1000$

Mammoth tips …..................10c $\$ \quad .60 \quad \$ 5.00 \$ \$ 40.00$

Loganberry tips …...................10 $\quad .60 \quad 6.00 \quad 50.00$



Gonseberries-Oregon,

Champion, English …...15̃c $1.25 \quad 5.00 \quad 45.00$

\section{CURRANTS}

Cherry, Transparent,

Each $\quad 10 \quad 100$

White, Black Naples ............10c $\$ .80 \$ 6.00$ Each 10 Table Grapes in variety .............................10 $80 \mathrm{c}$

\section{WALNUTS}

Grafted on California Black

Each 10

4 to $6 \mathrm{ft}$.

$\$ 1.50 \quad \$ 12.50$

3 to $4 \mathrm{ft}$.

1.2510 .00

\section{PERSIMMON}

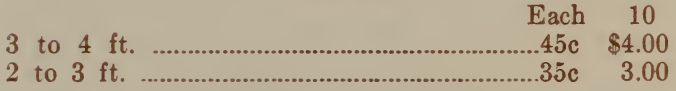

\section{ROSES}

Newer and Scarce Varieties at $30 \mathrm{c}$ each. American Beauty, rich, red, very fragrant. Antoine Rivorie, rose-flesh and ivory on yellow ground.

Bessie Brown, white flushed with pink.

Blumenschmidt, pure citron yellow petals edged 
Etoile de France, brilliant shade of clear red crim. son.

Frau Karl Druschki, the white American Beauty.

Freiherr von Marschall, deep carmine red.

Gen. McArthur, bright crimson scarlet.

Joanne Wessenhoff, clear lustrous yellow.

Killarney, brilliant sparkling pink.

Oriole, clean golden yellow.

Perle von Godesburg, the yellow Kaserin-fine.

Richmond, bright red, very fragrant.

New Climbers at 30c each.

Mad. Car. Testout, a rank pink climber.

Mar. Neil (hard to propogate), fine beautiful yellow. Papa Gontier, a strong climber resembling the bush. Gainsborough (Vis. Folkstone), a beautiful satiny rose.

Bush Roses, 1 yr., at 30c each.

Anne De Diesbach, brilliant carmine.

Agrippina, deep crimson.

Augusine Guinoiseau, (white La France), white, slightly tinged pink.

Baby Rambler, crimson, in clusters.

Bride, white, tinged rose.

Bridesmaid, clear bright pink.

Balduin (Helen Gould), rich, rosy crimson.

Catherine Mermet, light flesh.

Cecile Brunner, rosy pink, small blooms in clusters. Christine de Noue (double Papa Gontier), deep glowing red.

Clara Watson, salmon-pink, very fine.

Conrad C. Meyer, pure silvery pink.

Duchess of Almany (red La France), darker than the pink.

Francisco Kruger, coppery rose.

Gen. Jacqueminot, shining crimson.

Helen Gould (Balduin, rich, rosy crimson.

Helen Good, delicate pink. Sport from Mam. Cochet. Kaiserine Augusta Victoria, creamy white.

La France, satin pink.

La Princess Zera, bright rose.

Mad. Abel Chatnay, carmine, shaded with salmon.

Mad. de Varty, bright, rich crimson-scarlet.

Mad. Car. Testout, brilliant, satiny rose. 
Mamon Cochet, rich, rosy pink-the queen of pink tea roses.

Marie Van Houtte, creamy-white, tinged with rose.

Papa Gontier, rich, rosy crimson.

Paul Neyron, dark rose, enormous size.

Queen Scarlet, brilliant velvety scarlet.

Rainbow (striped Papa Gontier), rose, striped with crimson.

Safrano, bright apricot.

Souv. de Pierre Notting, a seedling of Marechel Neil and Mam. Cochet.

Ulrich Brunner, bright clear red.

Souv. de Pres. Carnot, delicate rosy blush.

Vis. Folkstone, creamy pink, shaded with white.

White Mamon Cochet, white, shaded with pink. A constant bloomer.

Wm. R. Smith, creamy white, with shading of pink. Climbers, 1 year, at $30 \mathrm{c}$ each.

Beauty of Glazenwood (Gold of Ophir), copper, carmine and sulphur.

Climbing Kaserin (Mrs. Robert Perry), large white. Cloth of Gold (Cromoetlla), bright clear yellow.

Crimson Rambler small crimson flowers. A rapid climber.

Cherokee, double, white flowers, rich foliage. Very rapid climber.

Cherokee, single, large single white flowers.

Golden Chain (Climbing Safrano), apricot yellow.

Lamarque, pure white.

Mad. Wagram (Climbing Paul Neyron), bright flesh pink.

Reine Marie Henrietta, rich crimson, fragrant. Best red.

White Banksia, small white flowers in clusters.

Yellow Banksia, small yellow flowers in clusters.

Coquette Des Apls, white, tinged with carmine.

White Killarney.

Huge Dickson, brilliant crimson, shaded with scar. let.

Rhea Reid, one of our finest, crimson scarlet.

Lady Hillington, an ideal yellow tea rose.

Duchess of Wellington, color saffron yellow.

Mad. Leon Pain, silvery pink, shaded with salmon. 
My Maryland, sweet scented, very pretty salmon pink.

Mrs. A. Ward, deep golden orange, shaded with creamy yellow.

Mad. Segond Webber, very deep, rich apricot-yellow.

Mrs. A. R. Wandel, rich apricot-yellow flowers of large size.

Mad. Alfred Carrier, rich orange white, tinged with yellow.

Yellow Rambler, yellow, hardy climbing rose.

\section{CAMILLAS}

Double red, pink, white, variegated.

12 to 18 in.

Each

18 to 24 in.

2 to $21-4$ in.

\section{THE BOSS TREE PROTECTOR \\ Made of Yucca Palm}

It is cheap, durable and quickly put on the tree. It prevents rabbits from destroying your trees. A sure protection against frost, sun burn, grass-hoppers or dry winds. Can be easily removed; will last for years.

\section{PRICES}

$10 \mathrm{in.}$ long

12 in. long $\$ 10.00$ per 1000

14 in. long $\$ 10.50$

16 in. long $\$ 12.00 "$ " "

18 in. long $\$ 13.00 "$ " " $\$ 14.00 "$

Printed by The Printshop, Sebastopol, Cal. 
